\title{
You Stab My Back, I'll Stab Yours: Management Experience and Perceptions of Organization Political Behaviour
}

\author{
David A. Buchanan \\ Cranfield University, School of Management, Cranfield, Bedfordshire MK43 0AL, UK \\ Email: David.Buchanan@Cranfield.ac.uk
}

This paper reports the findings of a survey of 250 British managers, exploring their experience and perceptions of organization politics. Political behaviour appeared to be common. Most managers viewed political behaviour as ethical and necessary, and aspects of organizational effectiveness, change, resourcing and reputation were attributed to political tactics, although $80 \%$ had no training in this area. Tactics experienced frequently included networking, using 'key players' to support initiatives, making friends with power brokers, bending the rules, and self-promotion. Tactics experienced as rare, but not unknown, included misinformation, spreading rumours, and keeping 'dirt files' for blackmail. A consistent pattern of responses concerning willingness to engage in politics, the need to act ruthlessly and the appropriateness of reciprocity when faced with political behaviour implies an attitude of 'you stab my back, I'll stab yours'. Findings are discussed using an 'antecedents-behaviours-consequences' framework of perceived organization politics to guide research. 


\section{The knowledge gap}

Organization politics are a reality in most organizations, and while game-playing might outwardly appear to be wasted time, it is necessary in order to secure resources, progress ideas, achieve personal goals and often to enhance one's standing. It is naive to realistically expect to be able to stand aloof from organization politics. You may be respected for doing so, but your progress will be limited and you will be seen as an easy target. (Middle manager, manufacturing, male, age 40-49)

Ferris et al. (1996, p. 262) argue that the field of organization politics remains largely unexplored, particularly with regard to subjective experience. Studies of perceptions of politics suggest the pervasiveness of such behaviour along with ambivalence towards this aspect of the management role. However, little is known about British managers' perceptions of organization politics. The focus of this study thus lies with the management experience, exploring the perceived implications for organizational change, individual performance, reputation and career. Has the significance of political behaviour been diluted by the values of openness, honesty and integrity, and through the advocacy of teamwork and compassionate, ethical leadership? The politicized nature of change is widely recognized (Dawson, 2003; Frost and Egri, 1991; Pettigrew, 1973), but the role of organization politics in change agency is controversial. Voyer (1994) and Peled (1999) argue for relevance, Ferris and King (1991) and Stone (1997) argue for avoidance, Kumar and Thibodeaux (1990) link the intensity of political activity to scale of change, and Cobb (1986) advocates a diagnostic approach to organization development interventions. One aim of this research, therefore, is to explore British managers' perceptions of these issues. A second aim is to identify further lines of enquiry, through developing a framework linking the perceived antecedents of organization politics, through political tactics, to perceived consequences. Most previous research on perceptions of organization politics is rooted in a positivist perspective, seeking to develop a generalizable model of the triggers, nature and outcomes of political behaviour. This study, in contrast, is based on a constructivist perspective. The resultant 'antecedents-behaviours-consequences' framework thus reflects the interpretation of these links as they are perceived by respondents. This framework does not represent an empirically testable model in a positivist sense, but instead codifies the 'actor-theory-in-use' of the management respondents in this study.

The lack of evidence may be attributed to the sensitive nature of the topic, inhibiting research access and candid responses. Madison et al. (1980) advise researchers to cloak the term with an appropriate euphemism, as it is 'too sensitive for use in direct investigations'. In feeding back to management her analysis of internally authored and politically motivated accounts of change, depicting the company's organization development function in a pivotal light, O'Connor's (1995) management contact described her account as shocking, outrageous and unacceptable, and never met with her again. A further inhibitor may lie with language. 'Machiavellian' is an insult, not a compliment, implying the use of cunning, devious, manipulative, underhand tactics. Calhoon (1969) describes political tactics as 'unsavoury'. Keen (1981) observes that politics is equated with 'evil, corruption, and blasphemy'. Ferris and King (1991) describe politicized decision-making as 'a walk on the dark side', echoed in Egan's (1994) 'shadow side' of management. Chanlat (1997) describes politics as a 'social disease'. It is hardly surprising that Jackall (1988) criticizes the 'emotional aridity' of managers who compromise a caring ethic by playing political games.

Field research in this area is thus problematic. Organization gatekeepers may dismiss requests to explore company politics; managers may not reveal tactics to strangers who will publish their findings. These issues have been addressed using safe research methods such as self-report questionnaires (Gandz and Murray, 1980; Vigoda, 2003), student respondents (Drory and Romm, 1988) and indirect studies of work attitudes and stress in university employees (Ferris et al., 1996). The study reported here used a survey instrument but was based on a constructivist-interpretive epistemology concerned not with measurement and covariation but with understanding how constructs and relationships are experienced and perceived by respondents.

\section{Terminology, evidence, theory}

The literature of organizational power and politics is extensive, and is broadly divided between macro- and micro-political approaches (Vigoda, 2003). Macro perspectives address structural bases of organizational power and the role of coalitions in promoting collective agendas (Bacharach and Lawler, 1981; Hickson et al., 1971; Pettigrew and McNulty, 1995; Pfeffer, 1992). Dominated by a positivist perspective, micro approaches focus on individual behaviour, relationships and perceptions (Burns, 1961; Ferris et al., 1996; Gandz and Murray, 1980; Kacmar and Ferris, 1991; Perrewé et al., 2000). Exploring perceptions of middle and senior managers, the research reported here adopts a micro approach, and the following overview focuses on three aspects of the relevant literature. The first concerns definitions of organization politics. The second concerns studies of the subjective experience of politics. Third, theoretical implications are considered, with regard to the perceived antecedents or triggers, 
behaviours or tactics, and consequences or outcomes of political behaviour. This 'antecedents-behavioursconsequences' framework is subsequently used to explore the implications of the findings of this study.

\section{Terminology}

The absence of a common definition of organization politics is a long-standing concern, and commentators continue to note the lack of agreement (Drory and Romm, 1990; Ferris et al., 2002a). Kacmar and Carlson (1997, p. 656) argue that 'Only when consensus is reached about what organizational politics is and how it should be measured will the field be advanced'. Points of contention concern distinguishing 'political' from 'non-political' actions, the treatment of self-interest as a defining characteristic, and the inevitably damaging nature of politics. Allen et al. $(1979$, p. 77) define politics as 'acts of influence to enhance or protect the self-interest of individuals or groups'. Mintzberg $(1983$, p. 172, 1985) defines politics as 'individual or group behaviour that is informal, ostensibly parochial, typically divisive, and above all, in the technical sense, illegitimate - sanctioned neither by formal authority, accepted ideology, nor certified expertise'. Valle and Perrewé (2000, p. 361) regard political behaviour as 'the exercise of tactical influence which is strategically goal directed, rational, conscious and intended to promote self-interest, either at the expense of or in support of others' interests'.

There are problems with the definition features involving influence, self-interest and damage. First, as Mangham (1979) and Astley and Sachdeva (1984) observe, all routine social exchanges entail mutual influence, and every interaction could thus be interpreted as political. An influence-based definition, therefore, does not readily distinguish political from non-political behaviour. Indeed, attribution theory suggests that it is important for managers to avoid having their actions labelled with political intent, and it may be necessary to create the impression that goals are selfless and non-political. Successful manipulation may be that which attracts attributions of legitimate motives (Allen et al., 1979, p. 82). Ferris et al. (2000, p. 30) thus define political skill as 'an interpersonal style construct that combines social astuteness with the ability to relate well, and otherwise demonstrate situation- ally appropriate behaviour in a disarmingly charming and engaging manner that inspires confidence, trust, sincerity, and genuineness'. Ferris et al. (2002b, p. 111) suggest that skilled political actors are those who are able to disguise their selfserving intent. A second problem is that political tactics can be used to promote either or both individual and organizational interests (Buchanan, 1999; Harrison, 1987). If political tactics can generate corporate benefit as well as personal gain, then definitions that regard only overtly self-interested acts as categorically political are unhelpful.

A third related issue concerns the widespread portrayal of organization politics in negative terms. Klein $(1988$, p. 1) argues that the claim that organizations are political is 'a myth propagated and entertained to address various needs of organizational members'. Accepting this myth makes it self-perpetuating, and political behaviour should instead be eliminated. Eisenhardt and Bourgeois (1988) argue that political behaviour in a top management team is associated with poor performance, by creating inflexibilities and communication barriers, restricting information flows, and consuming time. Zaleznik (1997) distinguishes between 'psycho- politics' and 'real work'. Personnel decisions, such as selection and performance evaluation, should be depoliticized, according to Ferris and King (1991). Ferris and Kacmar (1992) discuss 'destructive opportunism and dysfunctional game playing'. Voyer's (1994, p. 84) study of a computer company concluded that politics were 'mostly dysfunctional' and that management should 'step in and reduce the level of politics'. According to Stone (1997), eradicating organization politics is a management duty.

Some commentators, however, argue that politics are useful. Mangham $(1979$, p. 16) observes that reasonable people often disagree, with regard to both ends and means, and can thus be expected 'to fight for what they are convinced is right and, perhaps more significantly, against that which they are convinced is wrong'. Butcher and Clarke (1999) view politics as 'battles over just causes', in which debate sharpens the quality of decisions. Gandz and Murray (1980) found that organization politics was considered functional in terms of careers and power-building. Harrison (1987) argues that political behaviour can be used to counter the use of legitimate tactics to achieve undesirable ends, and to help implement decisions reached by legitimate means. Frost and Egri (1991) argue that political struggles play a role in resolving competing perspectives and interests in the context of organizational changes. McClelland and Burnham (1995) distinguish between institutional (socialized) and personal uses of power, the latter for personal gain, the former in the interests of group and corporate goals, potentially involving self- sacrifice. For Keen (1981) and Hardy (1996), organizational power and politics provide the dynamic for the implementation of strategic change. The history of conflicting interests, alignments and negotiations, argue Bacharach and Lawler (1998), is the history of change. For Provis (2004, p. 233) the widely varied circumstances of political behaviour mean that the claim 'politics is always bad' is 'an easy view that we can set aside'. 
The debates concerning terminology and the functional or dysfunctional properties of organization politics arise in a positivist perspective, concerned with operationalizing core concepts, developing valid and stable measures, establishing covariation and building generalizable models. From a constructivist perspective, the definitions and assessments that matter are those of organizational members.

\section{Subjective experience}

What is already known about the subjective experience of organization politics? In one of the first studies in this field, Gandz and Murray (1980) found from their survey of 400 American managers that $90 \%$ regarded politics as commonplace, and $89 \%$ said that executives had to be skilled politicians. However, $55 \%$ said that politics impeded efficiency, and 50\% argued that management should eliminate politics. Allen et al. (1979; Madison et al., 1980) interviewed 87 senior and middle managers from 30 Californian electronics companies. Political tactics mentioned most frequently were blaming others, selective information, creating a favourable image, developing support, ingratiation, creating obligations, rewards, coercion and threats, associating with influential individuals, and forming powerful coalitions. In addition, $60 \%$ of respondents said that political behaviour was either 'frequent' or 'very frequent'. While $60 \%$ agreed that political behaviour can advance careers, respondents were unanimous that politics can harm individuals, through loss of job, power, strategic position and credibility. However, $45 \%$ claimed that politics impeded goal achievement, and a third claimed that politics resulted in the misuse of resources. Given this blend of outcomes, Madison et al. (1980, p. 93) describe politics as a 'two-edged sword'.

Drory and Romm (1988) asked 156 employees (also Israeli university and college students) to assess the political nature of 15 critical influencing incidents, based on 'definitional elements' of politics, including informality, conflict, acting against the organization, power attainment, and concealed motives (see Drory and Romm, 1990). The argument that all behaviour is political was not supported. Formal influence attempts, and the presence of conflict, were not necessarily seen as political (conflict can be resolved by other means). Perception of behaviour as political appeared to depend on characteristics of the situation and the observer; managers perceived those definition elements as less political than employees in non-supervisory positions.

Exploring links between organization politics and job attitudes, Drory (1993) surveyed 200 supervisors and employees in five Israeli organizations. Pilot interviews with 25 employees were used to develop a measure of 'political climate' based on key decisions affecting task and budget allocations, performance appraisals and organization structure, and survey respondents were asked to indicate whether these decisions were influenced by political factors. The findings suggest that lower status employees, lacking the power and influence to benefit from 'the political game', view politics as frustrating, but higher status employees did not associate politics with job dissatisfaction. Drory argues that political behaviour is an entrenched organizational feature, that in some circumstances this may be an appropriate aspect of decision-making, that negative outcomes cannot always be avoided, and that further research into political consequences is required.

Ferris and Kacmar (1992) report two studies linking perceptions of politics to contextual and personal factors. The first involved 264 managers and employees from three organizations. A 'perception of politics' measure included the incidence of favouritism, keeping the boss happy, avoiding criticism, and forming 'in groups'. Those at lower levels perceived a higher degree of politics than those at higher levels, and the perception that the workplace was political was again associated with job dissatisfaction. The second study involved 95 hospital nurses and their supervisors, who completed a questionnaire measuring organization politics, job satisfaction, job and work environment factors, and personal influences. Findings suggest that politics can have positive individual and organizational consequences. The authors conclude that research should adopt a neutral perspective, exploring links between political proficiency and job- and career-related rewards (Ferris and Kacmar, 1992, p. 113). However, using a Machiavellian personality assessment (the 'Mach IV' from Christie and Geiss, 1970), Graham (1996) found that 'high Mach' managers did not have more successful careers (defined by salary) than 'low Machs'.

Ferris et al. (1996) explore the links between politics and dissatisfaction, anxiety and stress, using a questionnaire returned by over 800 nonacademic university employees. Perceptions were measured using a 40item scale with items such as 'favouritism rather than merit determines who gets ahead around here' and 'I have seen changes made in policies that only serve the purposes of a few individuals'. Centralization (concentrating power at the top) was positively related to perceptions of politics, and formalization (reducing uncertainty and ambiguity) was negatively related. Those who saw their organization as highly political showed higher levels of anxiety and lower satisfaction with both job and supervision. Lower level 
employees, and those who rated their career opportunities as low, perceived higher levels of politics, and male respondents saw more political behaviour than female. Little is known about gender differences in organization politics. However, from her interview study of 55 senior female American managers, Mainiero (1994, p. 19) found that, while most initially denied that political skill had contributed to their career success, they had actually progressed by experience through a 'seasoning process', following which they were practising 'political skill at a very high and subtle level'.

Our understanding of perceptions of politics thus relies primarily on surveys of mixed occupational groups of American and Israeli employees and managers. The evidence suggests that, while the incidence of behaviours perceived to be political is high and political tactics are seen to generate both positive and negative individual and organizational outcomes, most managers dislike this dimension of their role.

\section{Theoretical implications}

Ferris and Kacmar (1992) argue that organization politics is a relatively under-theorized field. Bacharach and Lawler (1998) note that the literature is fragmented, with commentators adopting unique perspectives, with no core set of problems to form the basis for theoretical debate. Consequently, there is no cumulative tradition leading to the development of a 'political theory of organizations'. Perhaps the most influential perspective in this regard has been the model of perceptions of organization politics developed by Ferris et al. (2002a, p. 235), hypothesizing how a range of outcomes, such as satisfaction, withdrawal, trust, performance and citizenship, depend on perceptions of politics that in turn depend on a range of organizational, environmental, demographic and personality factors. That model, and commentary reviewed here, reflects an 'antecedents-behaviours-consequences' framework, linking triggering or precipitating conditions, with political tactics or strategies, to a range of individual and organizational outcomes. Conceptualizing this approach in a simplified three-step framework facilitates comparisons between positivist studies of perceptions of politics and the constructivist perspective adopted in this research. Thus, while the model of Ferris et al. (2002a) seeks to identify a generalizable set of causal links, the framework developed through the study reported here seeks instead to codify how the links between antecedents, political behaviours and consequences are understood by organization managers.

While most perspectives attribute political behaviour to the pursuit of self-interest, Chanlat (1997) argues that triggers also lie with personal ambition, the prevalence of unstructured problems (which cannot be resolved through simple decision rules), and structural differentiation (generating competition for resources). The contingency model of Kumar and Thibodeaux (1990) locates the triggers of political behaviour with the significance of organizational change. First-level change in this model involves improving effectiveness. Second-level change involves the introduction of new perspectives. Third-level change concerns organizationwide shifts in values and working practices. The more significant the change and its implications, the greater the political involvement required by the change agent. Kumar and Thibodeaux thus argue that, while first- and second-level changes require political awareness and facilitation respectively, third-level change entails political intervention, which may involve stimulating debate, gaining support from key groups, and covert manipulation (tactics which they accept may be 'ethically objectionable' but which reflect the 'distasteful reality' of organization politics).

Ferris and Kacmar (1992), Drory (1993) and Ferris et al. (1996) variously attempt to model links between perceptions of political behaviour and consequences for job attitudes. Allen et al. (1979), Madison et al. (1980) and Ferris and Kacmar (1992), along with Kumar and Thibodeaux (1990), identify political tactics which potentially lead to individual and organizational consequences. Perrewé et al. (2000) argue that political skill, through improving interpersonal control and feelings of efficacy and self-confidence, reduces management role stress.

Table 1 summarizes the strands of this commentary concerning reported antecedents or triggers of organization politics, the behaviours or tactics deployed, and the consequences or outcomes, and is based on Allen et al. (1979), Mangham (1979), Madison et al. (1980), Gandz and Murray (1980), Keen (1981), Harrison (1987), Drory and Romm (1988), Eisenhardt and Bourgeois (1988), Drory and Romm (1990), Kumar and Thibodeaux (1990), Ferris and King (1991), Frost and Egri (1991), Ferris and Kacmar (1992), Drory (1993), Voyer (1994), McClelland and Burnham (1995), Ferris et al. (1996), Hardy (1996), Chanlat (1997), Stone (1997), Bacharach and Lawler (1998), Buchanan (1999), Butcher and Clarke (1999), Mainiero (1994), Ferris et al. (2000), Perrewé et al. (2000), Ferris et al. (2002a, p. 235), Vigoda (2003) and Provis (2004). A distinction is made between individual and contextual antecedents, suggesting that political behaviour can be triggered by factors other than self-interest. The summary of reported tactics indicates a broad behaviour repertoire. The individual and organizational consequences, functional and dysfunctional, are also varied. While this tabulation implies testable causal links across the framework, 
it is not presented in support of such claims. Rather, this tabulation serves, first, to illustrate the range of potential antecedents, behaviours and consequences of political behaviour, and second, as a basis for comparison with 'actor-theory-in-use' concerning perceived antecedents, behaviours and consequences as these appear to be understood by respondents in the research reported here.

Table 1. Reported antecedents, behaviours and consequences of organization politics (literature summary)

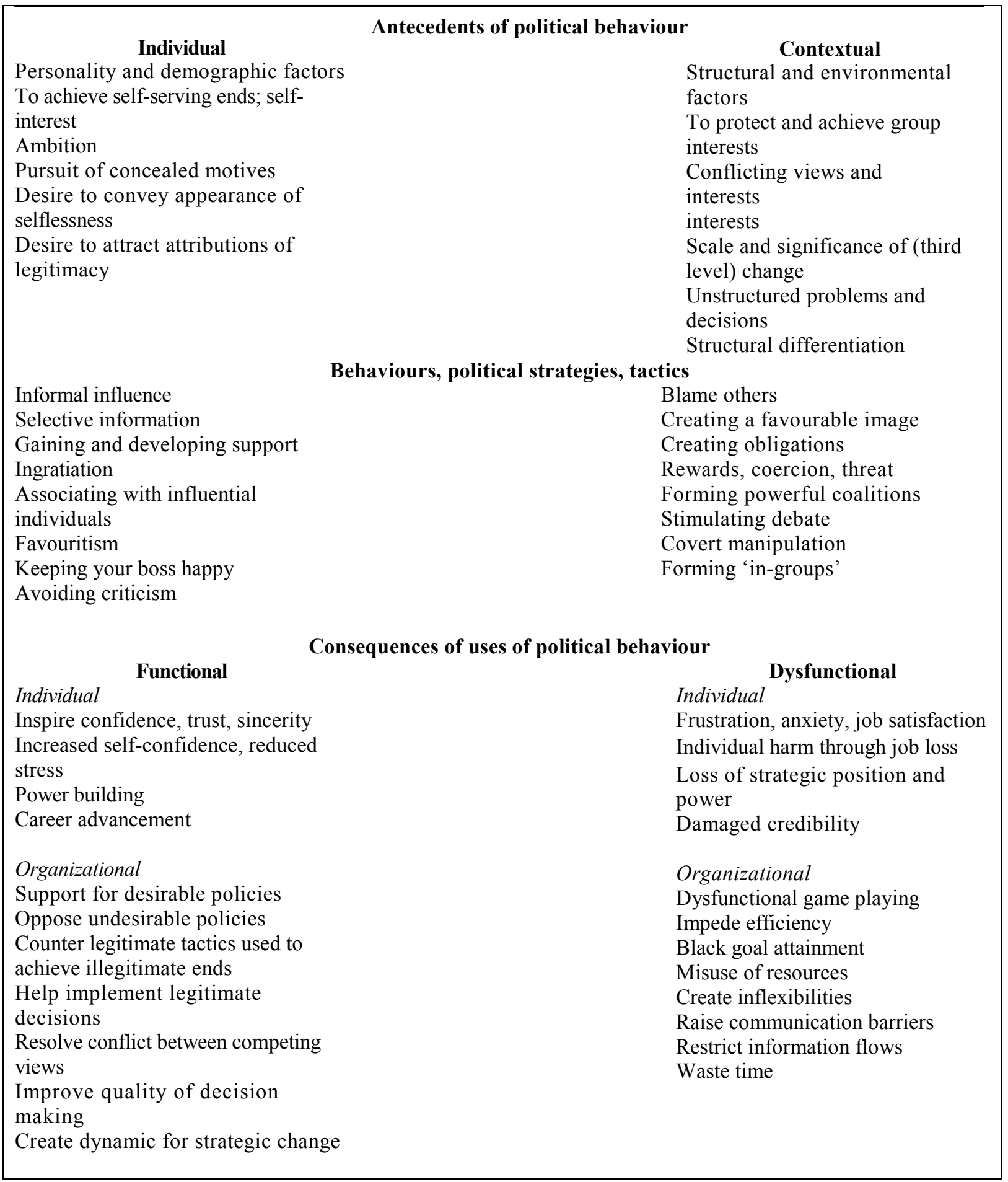

\section{Research orientation and method}

This research is based on a qualitative constructivist-interpretivist orientation (Deetz, 1996) involving four points of contrast with previous quantitative positivist studies of perceptions of organization politics. First, as indicated earlier, political behaviour is a socially constructed phenomenon (Ferris et al., 2002a, p. 211), and researcher-derived definitions are thus of secondary importance to the definitions and interpretations of respondents. Second, as behaviour only becomes 'political' when actors or observers label it as such, a 
constructivist orientation rejects the distinction between perceptions of politics and actual political behaviour (Ferris et al., 2002a; Valle and Perrewé, 2000; Vigoda, 2003). The operationalization of actual political behaviour in the positivist tradition relies on the influence tactics identified by Kipnis et al. (1984). This means that, for example, 'rational appeal' (providing information), 'assertiveness' (giving an order) and 'exchange' (swapping favours) are categorically political behaviours, although actors in a given context may not always understand or label those actions in that way. The same argument applies to the categorical distinction between 'proactive' and 'reactive' defensive political behaviours (Valle and Perrewé, 2000). Other commentary (e.g. Buchanan and Badham, 1999; Schrijvers, 2004) suggests that managers use a range of methods for distracting, subverting, delegitimating, blocking, delaying, networking, positioning, coalition building, outmanoeuvring and otherwise promoting initiatives at the expense of others in addition to more conventional influence tactics. Third, the survey approach adopted for this study makes no claims to develop 'valid and stable measures' of key constructs. Instead, the objective is to explore patterns in experiences and perceptions, in order to develop a better understanding of how managers view and interpret political behaviour, its triggers and its outcomes. Echoing Mohr's (1982) critique of variance perspectives in organizational behaviour, a constructivist orientation suggests that measures of ambiguous and socially constructed phenomena, such as organization politics, are invariably unstable, and that observed patterns may only apply to particular respondent groups for a limited time. Fourth, this constructivist approach seeks to codify the 'actortheory-in-use' of management respondents, and not to develop a general causal model.

Consequently, this paper reports the findings of a survey of over 250 British managers. While a self-report questionnaire is not the first method of choice for qualitative constructivist research (Stoker, 2003), this approach has the advantages of generating a sizeable sample without having to negotiate organizational access, while providing confidentiality to encourage candid responses and facilitating comparison of results with previous survey-based research. The study was based on a purposive opportunity sample, using eight groups participating in management development programmes directed by the researcher. In contrast to many previous studies that have sampled across organizational levels, respondents here were middle and senior managers, and the probability of these managers having experience of organization politics was high. Care was taken not to pre-sensitize respondents to the survey contents, and where this was not possible the instrument was not administered.

The survey instrument guaranteed anonymity and was designed for ease of completion, with five sections. The first section asked respondents to rate 18 behaviours in terms of how often they had been experienced. Those items were not derived a priori on theoretical grounds or from literature (such as the perception of organization politics scale designed by Kacmar and Ferris, 1991), but relied on a series of tactics that managers themselves had previously identified as examples of political behaviour (Buchanan and Badham, 1999).

Two sections next contained 30 Likert-scaled items addressing general perceptions of organization politics. Fourth, a further 15 Likert-scaled items considered aspects of the personal, organizational and changerelated consequences of political behaviour. Finally, respondents were asked for background and context information (gender, age range, management level, sector, nationality, experience of change management, training in politics, qualifications). Items that could provide identity cues were excluded. In addition, five 'true or false' items explored sensitive issues relating to interpersonal harm. A 'comments box' invited open remarks; around $10 \%$ of respondents used this opportunity. The sample characteristics were

- 252 respondents;

- from over 107 organizations (some respondents withheld employer's name);

- $46 \%$ male, $54 \%$ female;

- $68 \%$ public sector, $32 \%$ private sector;

- $44 \%$ senior managers, $38 \%$ middle managers, $15 \%$ professional, $3 \%$ 'other';

- $78 \%$ had no training in dealing with organization politics;

- $15 \%$ indicated that change management was their full time role;

- $86 \%$ regarded change management as one dimension of their role;

- $88 \%$ said their organization was under external pressure to change. 
One evident sample bias concerns public sector dominance. However, sectoral differences in responses were not detected. One explanation is that the experience of politics is not sector- dependent. VigodaGadot and Kapun (2005) found that public sector employees view their organizations as more political, unfair and unjust than private sector employees, but their respondents included a cross-section of occupations rather than focusing on managers. Respondents for the study reported here, in contrast, were managers recruited through management development programmes, suggesting a bias for career mobility, reinforced by the observation that over $70 \%$ had a university degree and over $50 \%$ had a management qualification. The absence of sector differences may also be explained by the exchange of managers between sectors and by responses based on general experience rather than on one organization. Most respondents also had experience of, and consequently a professional interest in, organizational change.

\section{Findings}

As this survey generated nominal and ordinal-scale data, only frequency distributions and crosstabulations are reported; no further statistical analysis was appropriate. Five main themes emerge, concerning

- the management experience;

- opinions and beliefs;

- organizational effectiveness and change;

- performance, reputation and career;

- gender differences.

\section{The management experience}

The experience of politics seems to be frequent, visible and sometimes painful. Only $12 \%$ agreed that 'my organization is relatively free of politics', and only $17 \%$ agreed that 'I don't see much political behaviour because it happens behind closed doors'. In contrast with previous studies, there were no job level differences in responses to those items (and no gender or sector differences either). Political behaviour was not seen as a senior management preserve; $83 \%$ agreed that 'politics is played at all organizational levels'. It is not surprising, therefore, that $84 \%$ agreed that 'I am prepared to play politics when necessary', $87 \%$ agreed that 'politics is a natural part of the management job' and 93\% agreed that 'most managers, if they want to succeed, have to play politics at least part of the time'. However, over $70 \%$ said that they had been hurt by the tactics of others.

The survey sought to establish the perceived frequency of 18 political behaviours. The results suggest a ranking, produced by considering first the response frequencies for 'very often', then the combined frequencies for 'very often' and 'often', and finally the aggregated frequencies for 'very often', 'often' and 'sometimes' for each tactic. This indicates three categories of more common, less common and rare tactics. At least $68 \%$ of respondents said that they had experienced all but three of those tactics at least 'sometimes'. Five behaviours were perceived as occurring more frequently: building a network of useful contacts, using 'key players' to support initiatives, making friends with power brokers, bending the rules to fit the situation, and self- promotion. Three tactics were rated as relatively rare: using misinformation to confuse others, spreading false rumours to undermine others, and keeping 'dirt files' to blackmail others. These results do not indicate the actual incidence of political tactics, but reflect management perceptions of how often such behaviours occur. Asked whether 'my organization would benefit from a higher level of organizational politics', only $8 \%$ agreed. Whatever the incidence of political behaviour, it appears that most managers consider that to be too high, confirming previous studies showing that increases in the perceived level of politics are linked to lower levels of job satisfaction, among employees in general (Harrell-Cook, Ferris and Dulebohn, 1999, p. 1095).

\section{Opinions and beliefs}

Respondents were asked to indicate which of four statements most accurately reflected their opinion of organization politics (Table 2). Almost two- thirds saw politics as an aspect of their role which they had to understand, but which they preferred to avoid. There were no job level differences in response to these items. However, women were more likely to choose 'understand but avoid' $(69 \%)$ than men (56\%), who were more likely to respond with 'necessary to play' (38\% compared with $24 \%$ ). Only $27 \%$ agreed that 'winning the political game is an intensely satisfying personal experience' (with no gender or job level differences). Asked if 'political behaviour is unethical', only $12 \%$ agreed ( $2 \%$ strongly), with $67 \%$ in disagreement. Consequently, $88 \%$ of respondents felt either that political behaviour was unethical or were unsure. 
Nevertheless, two comments described politics as 'evil'.

Organization politics is a 'necessary evil' but need not necessarily be seen as a wholly negative concept. Often it is the informal route by which legitimate objectives are achieved. In my experience, organizational politics is a fact of life. (Senior manager, manufacturing, male, age 30-39)

I dislike it intensely, but recognize it as an evil others make me engage in. (Middle manager, public sector hospital, male, age 30-39)

Table 2

\begin{tabular}{|l|c|}
\hline $\begin{array}{l}\text { I don't want to be involved in organization politics, but } \\
\text { it is necessary to understand what is going on }\end{array}$ & $63 \%$ \\
\hline $\begin{array}{l}\text { I believe it is necessary to play politics to achieve my } \\
\text { objectives and enhance my reputation }\end{array}$ & $31 \%$ \\
\hline $\begin{array}{l}\text { I play politics because it is challenging and fun and is an } \\
\text { important motivator for me }\end{array}$ & $3 \%$ \\
\hline $\begin{array}{l}\text { I ignore politics because it is unethical, demotivating, } \\
\text { unacceptable and would damage my reputation }\end{array}$ & $3 \%$ \\
\hline
\end{tabular}

Are political tactics considered inappropriate in some circumstances? Around $80 \%$ indicated that they were not prepared to hurt others with political tactics, and over $80 \%$ denied that they had hurt others in this way. However, there were interesting gender differences in responses to these 'true-false' items. Reflecting conventional 'tough and tender' stereotypes, a higher proportion of men said that they were prepared to hurt others to achieve personal and organizational goals, and men were more likely to admit that they had hurt others. However, women were more likely to agree that playing politics had contributed to their career (Table 3).

Not all political behaviour is a source of discomfort; $65 \%$ agreed that 'some managers play politics just for fun'. On the item 'most managers dislike playing politics', the sample was divided, with only $17 \%$ agreement, $34 \%$ unsure and $50 \%$ in disagreement ( $2 \%$ strongly). Asked whether 'life without organization politics would be boring', $38 \%$ agreed (with $21 \%$ unsure, $41 \%$ in disagreement), and only $32 \%$ agreed that 'my ideal organization is one with no politics' (with $21 \%$ unsure and $48 \%$ in disagreement). It thus appears that between one-third and a half of respondents held broadly positive views of organization politics.

With $81 \%$ and $75 \%$ agreement respectively that 'I am prepared to play politics when necessary' and 'I engage in political behaviour when necessary to achieve my objectives', responses to two additional items indicate a more calculating perspective. For example, $72 \%$ agreed that 'a manager has to be ruthless sometimes', and $89 \%$ agreed (16\% strongly) that 'those who use political tactics should expect to have similar tactics used against them' (with no gender differences in responses to those items). This consistent response pattern suggests that political tactics are considered justified in some contexts, that causing harm is less acceptable and that 'ruthless reciprocity' is perceived appropriate, implying an attitude of 'you stab my back, I'll stab yours'. How can willing ruthlessness be reconciled with the desire to avoid hurting others? This sentiment is perhaps captured by the following comment.

While I 'agreed' with it, I don't feel comfortable with the word ruthless, as there is an element of vindictiveness implied by the word. (Senior manager, public sector hospital, male, age 30-39) 


\begin{tabular}{|l|c|c|}
\hline & $\begin{array}{c}\text { Male ‘true' } \\
\text { response (\%) }\end{array}$ & $\begin{array}{c}\text { Female 'true' } \\
\text { response (\%) }\end{array}$ \\
\hline $\begin{array}{l}\text { My willingness to play organization politics has contributed to my career } \\
\text { success }\end{array}$ & 45 & 55 \\
$\begin{array}{l}\text { If necessary to achieve organizational goals, I am prepared to hurt others } \\
\text { with political tactics }\end{array}$ & 31 & 11 \\
$\begin{array}{l}\text { If necessary to achieve personal goals, I am prepared to hurt others with } \\
\text { political tactics }\end{array}$ & 31 \\
\begin{tabular}{l} 
I know that I have hurt others with my use of political tactics \\
\hline
\end{tabular}
\end{tabular}

One explanation is that ruthlessness is equated more with impersonal management actions (closing facilities, cutting budgets, declaring redundancies), while hurting another individual is personal, and is more difficult to do - or to admit to doing.

How do senior management actions influence political behaviour? It appears that senior management are believed to be more involved in political behaviour, with $87 \%$ agreeing that 'the higher you go in the organization, the more political the climate becomes'. Senior managers appear also to be regarded as role models, with $84 \%$ agreeing that 'when the top team play politics, other managers follow their example'. There were no job level differences in responses to those items. However, while $23 \%$ agreed that 'senior management could stop the politics if they wanted to', senior managers appeared less confident than middle managers of their ability to do so, with $72 \%$ of senior managers compared with $45 \%$ of middle managers expressing disagreement.

Does the incidence of political behaviour vary? Only $21 \%$ indicated that 'the level of organization politics is constant', and $77 \%$ agreed that 'the degree of political behaviour varies over time'. Does organizational change intensify political activity? Only $20 \%$ agreed that 'you only see high levels of politics during periods of organizational change'. There were no sectoral differences in response to those items. Respondents were asked to indicate whether 'there is more organization politics today than five years ago'; 49\% agreed. However, more public sector respondents (52\%) agreed that there were 'more politics' than private sector managers (43\%). These findings are inconclusive, contradicting the thesis of Kumar and Thibodeaux (1990) and indicating that further investigation of factors influencing political intensity might be a fruitful topic for further investigation.

\section{Organizational effectiveness and change}

Do managers regard politics as a useful tool, or as an impediment, with respect to implementing change and improving organizational effectiveness? The findings indicate that the answer is contingent on the way in which tactics are deployed. On the one hand, $85 \%$ agreed (26\% strongly) that 'I have seen organization politics damage organizational effectiveness'. But more than half of respondents $(53 \%)$ had experienced politics contributing to organizational effectiveness.

The significance of political behaviour in change appears to be widely acknowledged:

- $60 \%$ agreed that 'politics become more important as organizational change becomes more complex';

- $79 \%$ agreed that 'politics can be used to initiate and drive useful change initiatives';

- $81 \%$ agreed that 'political tactics can be effective in dealing with resistance to change';

- $85 \%$ agreed that 'major changes need to be "steered" through the organization politics'; and

- $93 \%$ agreed (21\% strongly) that 'politics can be used to slow down and block useful change initiatives'. 
Only $24 \%$ felt (4\% strongly) that 'major changes must be free from organization politics if they are to be effective'. In addition, only 9\% agreed with the item 'change agents who avoid organization politics are more likely to succeed in their roles'. As other studies have suggested (Buchanan, 2003; Ferris et al., 2000), the effectiveness of organizational change is dependent, at least in part, on the political skill of change drivers, agents, catalysts or leaders.

Performance, reputation, career

The view that political skill is central to personal reputation and career, as well as to aspects of management performance, also seems to be widely recognized. The findings suggest that managers who ignore organization politics may damage their reputations, their careers and also the sections for which they are responsible. As noted earlier, over $90 \%$ agreed (19\% strongly) with the item 'most managers, if they want to succeed, have to play politics at least part of the time'. This is broadly consistent with the $72 \%$ disagreement with the item 'it is not possible to do a good job and play politics at the same time':

- $90 \%$ agreed that 'managers who play organization politics well can improve their career prospects';

- $81 \%$ agreed that 'personal reputations can be enhanced by appropriate political game playing';

- $75 \%$ agreed that 'the departments of skilled organization politicians attract higher levels of resource'; and

- $60 \%$ agreed that 'managers who are not prepared to play politics see their careers suffer'.

There were no gender differences in responses to those four items. Responses to three other items indicate the potential risks in avoiding organization politics:

- $83 \%$ agreed that 'departments in my organization use politics to try and win the competition for resources';

- $71 \%$ agreed that 'managers who don't play politics are pushed aside by those who do'; and

- $71 \%$ agreed that 'the departments of managers who are politically unskilled suffer in resource terms'.

There would appear to be a widespread perception that managers unable or unwilling to engage in organization politics jeopardize the resourcing of the sections for which they are responsible, as well as their careers.

Gender differences

Only $13 \%$ agreed that 'women are better at playing politics than men'; the modal response (47\%) was 'unsure'. A higher proportion of women (52\%) than men (41\%) disagreed with this item. Also, 27\% agreed that 'men play more political games than women'; the modal response $(41 \%)$ was again 'unsure'. However, more women (31\%) agreed that men play more political games than men do (18\%). These results are inconclusive. One possibility is that there are no gender differences; the motives, organizational infrastructures and access to resources are equivalent for all players in the politics game. Another explanation is that the differences are too subtle and complex for a survey questionnaire to capture. Other responses indicate that, while women are as willing as men to engage in politics, women express more concern for potential interpersonal harm. While Kanter (1979) and Mann (1995) argue that women are disadvantaged in the acquisition of organizational power, Arroba and James (1988) argue that women need to be politically aware and 'wise', exploiting innate advantages such as intuition, sensitivity, observation and a willingness to engage with feelings. Recent anecdotal evidence, however, suggests that many women reject management roles because of their distaste for political behaviour (Arkin, 2004).

\section{When necessity commands: actor-theory-in-use}

My view is that organizational politics are almost inevitable, but they can be constructive or destructive. The best management skills would seek to ensure that constructive uses, such as attraction of resources, or changed working practices, are delivered through using supportive political skills (especially with external partners). The worst skills are tantamount to bullying and dishonesty which should not be condoned. (Middle manager, public sector hospital, female, age 30-39)

Table 4 summarizes the findings from this study, following the format of the 'antecedents-behavioursconsequences' framework in Table 1. It is important to repeat that, unlike the model developed by 
Kacmar and Ferris (1991) and Ferris et al. (2002a), designed to be subject to objective empirical test, the framework in Table 4 illustrates the subjective understanding of respondents concerning the triggers, behaviours and outcomes of organization politics. In other words, Table 4 codifies the actor-theory-in-use that managers appear to use with respect to organization politics.

This evidence confirms that the use of political tactics is perceived to be widespread, generating both beneficial and dysfunctional individual and organizational outcomes (Drory, 1993; Ferris and Kacmar, 1992; Gandz and Murray, 1980). While this study was not designed to test theory linking the triggers, substance and outcomes of political behaviour, it is instructive to consider the findings under those headings, with regard to antecedents, consequences and further research.

Table 4. Perceived antecedents, behaviours and consequences of organization politics (research summary)

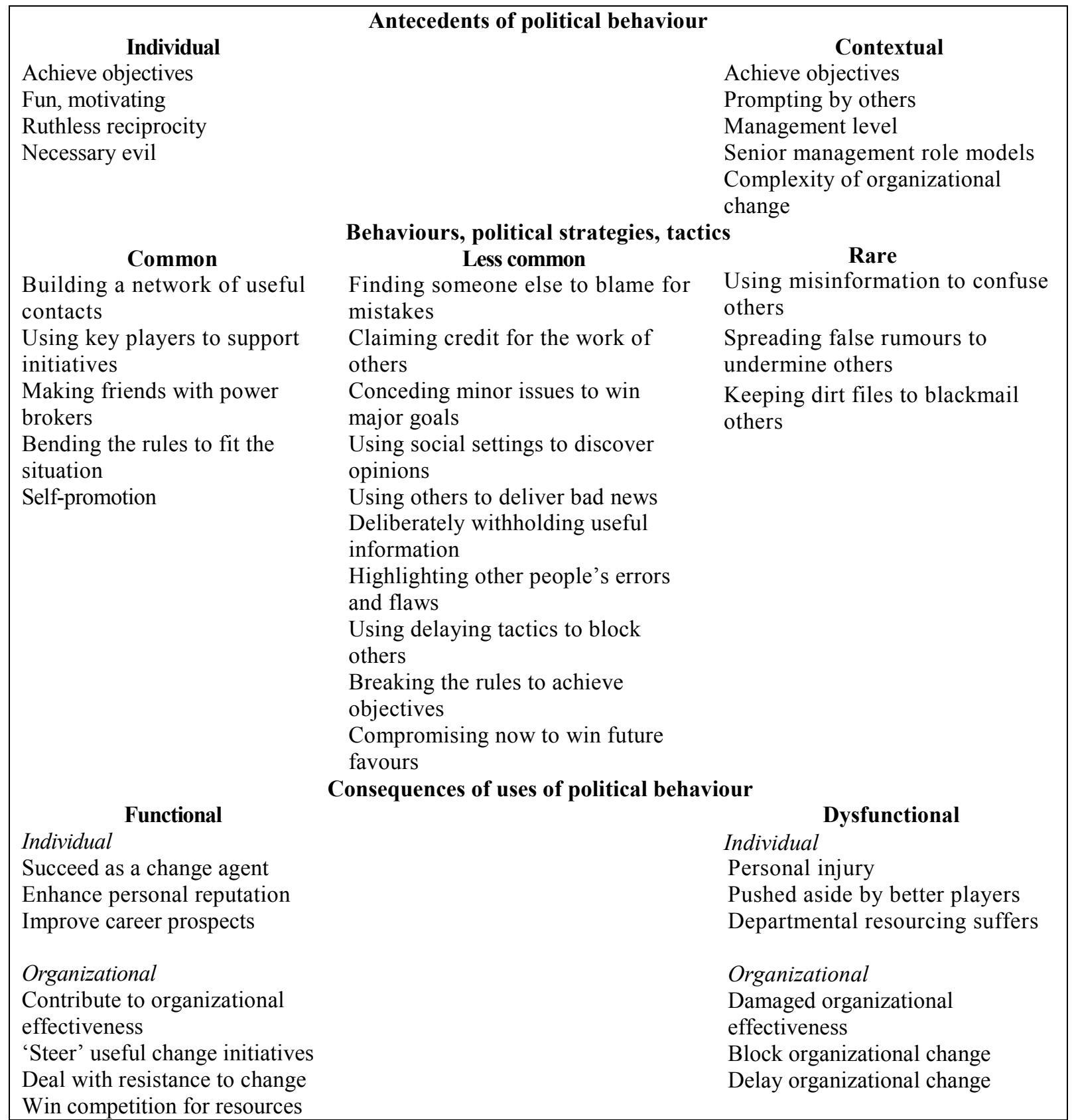

\section{Antecedents}

The results with regard to the factors that are perceived to trigger political behaviour confirm previous studies, suggesting a combination of individual and contextual factors, but including fun, motivation and reciprocity, as individual triggers, and change complexity, political actions of others, managerial level and 
senior management role modelling, as organizational triggers. Political behaviour seems to be widely perceived as a 'necessary evil', but ethical considerations appear to present no barrier to the deployment of such tactics for most respondents. While most agreed that they were prepared to play politics to achieve objectives, around two-thirds (but a higher proportion of women than men) indicated that, although it was important to understand this aspect of organizational behaviour, they would prefer to avoid it. Most would like their organizations to be less political. Over two-thirds claimed that political tactics had caused them injury, and most indicated that they gained no satisfaction from winning a political exchange. Women appear to engage in political tactics as readily as men, but seem less prepared to hurt others; a higher proportion of men admitted to injuring others through political tactics. Given the pervasive nature of organization politics, and the range of precipitating conditions, calls to depoliticize management behaviour (Klein, 1988; Stone, 1997) imply an agenda which even senior managers would find challenging.

This evidence suggests that previous studies may have underestimated the readiness of managers to overcome their ambivalence, and 'to enter into evil when necessity commands' (Machiavelli, 1961, ch. xviii). The consistently high degrees of willingness to engage in politics, to act ruthlessly, and to reciprocate in kind when dealing with others who use political tactics imply an attitude of 'you stab my back, I'll stab yours'. Indeed, that ambivalence may be significantly diluted by the perception that organization politics is necessary, ethical and fun.

\section{Behaviours}

Previous studies have focused only on common political tactics. The evidence from this study confirms the richness of the behaviour repertoire in this respect, while indicating the perceived prevalence of different tactics. Five tactics were perceived to be more common: building networks, using 'key players', befriending power brokers, bending rules, and self-promotion. Three tactics were seen as rare (but not unknown): using misinformation to confuse, spreading rumours to undermine, and keeping 'dirt files' to blackmail others. Considering those common and rare tactics, interpersonal manipulation and impression management may be perceived as socially more acceptable and less hurtful than behaviours which involve dishonesty and coercion.

\section{Consequences}

Again confirming previous studies, organization politics is perceived to generate a combination of functional and dysfunctional individual and organizational outcomes. The impact of politics on change and organizational effectiveness appears to be widely recognized, blocking or driving initiatives, of value in handling resistance to change, and disrupting or contributing to effectiveness (itself an ambivalent and politically charged concept). Most managers thus believe that change agents must be politically skilled. Extending the findings of Gandz and Murray (1980), most managers attribute success in reputation, career and resourcing, at least in part, to the exercise of political skill. Graham's (1996) attempt to establish a link between political skill and career may have foundered on the narrow measures used to operationalize skill ('Mach IV' scores) and success (salary). In-depth qualitative studies of behaviours and outcomes may reveal other links and outcomes.

\section{Theoretical implications}

The evidence suggests that the political theory of organization held by most managers incorporates the following propositions. First, political behaviour may be precipitated by a combination of individual and contextual factors, and is not necessarily perceived to be self-serving. Second, the behaviour repertoire of the organization politician is diverse, and while 'social' tactics may be perceived as more acceptable than covert manipulation, most managers see no ethical impediments to the use of political tactics. Third, political behaviour is not necessarily seen as damaging, but is perceived to generate both functional and dysfunctional individual and organizational consequences. While perhaps capturing the essence of current understanding in this field, these broad propositions leave several significant questions unanswered.

This study has considerable limitations. The survey approach has a number of advantages but still represents a methodological compromise. Survey methods struggle to capture the dynamics of political games unfolding through a series of overt and covert manipulations and influence attempts, involving shifting combinations of individuals and coalitions (Bacharach and Lawler, 1998). A questionnaire cannot explore in depth the temporal and contextual dimensions of those processes. Survey methods can only sketch the outlines, revealing broad patterns and trends, and indicate issues for further study, with different samples, deploying other research methods. The sample is purposive and nonrandom, displaying a bias towards the public sector and to well-qualified managers with experience of 
organizational change; statistical generalizations to a wider population cannot be confident.

Nevertheless, it is reasonable to consider the transferability (Lincoln and Guba, 1985) of the findings from this study to the wider management population. Confidence in that transfer is strengthened by the consistency of the response patterns, and by the extent to which the results of previous studies (rooted in a contrasting epistemology) are broadly supported. Confirmation of the findings from previous research suggests a degree of shared experience across different cultural and organizational settings. It is also reasonable to invite management readers to compare the resultant codified theory-in-use with their own perceptions and experiences (Stake, 1994, describes this process of reflection as naturalistic generalization). It is perhaps also reasonable to speculate with regard to the practical implications that arise should that actor-theory-in-use indeed be widely held by other managers.

A number of further lines of enquiry are thus indicated. As this topic has been studied mainly from a positivist perspective, the discursive processes through which behaviours come to be labelled as political, attributed with political intent, and socially constructed as political remain unexplored. The nature and significance of gender differences in this domain are not well understood, either by researchers or, it seems, by managers. While political behaviour is perceived to vary in intensity, little is known about the triggering and dampening mechanisms that are perceived to cause variation. Political skill is perceived to be central to the role of change agent, and while Ferris, Buckley and Allen (1992) advocate a 'balance' between 'pure politician' and 'demonstrated ability', little is known about the development of that balance, presumably acquired as an individual's moral standards and ideals are tested and compromised by organizational realities (Jackall, 1988; Provis, 2004). Mainiero's (1994) study of female American senior managers is an exception in this regard. While reputation and career success are attributed to political skill, the conditions and processes through which political behaviours affect reputation are unclear. There appear to be no cross-cultural comparisons of management experience and perceptions of organization politics. Critically, little is understood concerning the combinations of circumstances in which the functional consequences of political behaviour, individual and organizational, are produced. While large-n quantitative research may be appropriate in some settings, the more subtle aspects of the nature, processes and implications of organization political behaviour may be more effectively revealed using innovative small-n qualitative methods.

Concern with value-driven ethical leadership appears to have done little to reduce either the perceived incidence or significance of political behaviour. Assuming that these findings may indeed apply to the wider management population, what implications for practice emerge? Management selection, particularly for change- related roles, should consider candidates' political as well as professional competencies. Understanding organization politics without personal involvement may not be a good option for managers in general, or for change agents in particular, concerned with reputation and career. Those following Zaleznik (1997), focusing on 'real work', avoiding 'psychopolitics', may jeopardize the flow of resources to their sections, damage their reputations for 'getting things done' and limit their promotion prospects. Business schools and others engaged in management development may identify opportunity in the finding that, despite the significance of this component of management and change agency roles, almost $80 \%$ of respondents said they had no training in dealing with organization politics.

\section{References}

Allen, R. W., D. L. Madison, L. W. Porter, P. A. Renwick and B. T. Mayes (1979). 'Organizational politics: tactics and characteristics of its actors', California Management Review, 22 (1), pp. 7783.

Arkin, A. (2004). 'The fairer sex', People Management, 10 (20), pp. 4042.

Arroba, T. and K. James (1988). 'Are politics palatable to women managers? How women can make wise moves at work', Women in Management Review, 3 (3), pp. 123-130.

Astley, W. G. and P. S. Sachdeva (1984). 'Structural sources of intraorganizational power: a theoretical synthesis', Academy of Management Review, 9 (1), pp. 104113.

Bacharach, S. B. and E. J. Lawler (1981). Power and Politics in Organizations: The Social Psychology of Conflict, Coalitions, and Bargaining. San Francisco, CA: Jossey-Bass.

Bacharach, S. B. and E. J. Lawler (1998). 'Political alignments in organizations: contextualization, mobilization, and coordination'. In R. M. Kramer and M. A. Neale (eds), Power and Influence in Organizations, pp. 67-88. Thousand Oaks, CA: Sage.

Buchanan, D. A. (1999). 'The logic of political action: an experiment with the epistemology of the particular', British Journal of Management, 10 (special conference issue), pp. 7388. 
Buchanan, D. (2003). 'Demands, instabilities, manipulations, careers: the lived experience of driving change', Human Relations, 56 (6), pp. 663-684.

Buchanan, D. and R. Badham (1999). Power, Politics and Organizational Change: Winning the Turf Game. London: Sage.

Burns, T. (1961). 'Micropolitics: mechanisms of institutional change', Administrative Science Quarterly, 55, pp. 257281. Butcher, D. and M. Clarke (1999). 'Organizational politics: the missing discipline of management?', Industrial and Commercial Training, 31(1), pp. 9-12.

Calhoon, R. P. (1969). 'Nicolo Machiavelli and the 20th century administrator', Academy of Management Journal, 12 (2), pp. 205212.

Chanlat, J.-F. (1997). 'Conflict and politics'. In A. Sorge and M. Warner (eds), Handbook of Organizational Behaviour, pp. 472480. London: International Thomson.

Christie, R. and F. L. Geiss (1970). Studies in Machiavellianism. New York: Academic Press.

Cobb, A. T. (1986). 'Political diagnosis: applications in organizational development', Academy of Management Review, 11(3), pp. 482496.

Dawson, P. (2003). Reshaping Change: A Processual Approach. London: Routledge.

Deetz, S. (1996). 'Describing differences in approaches to organization science: rethinking Burrell and Morgan and their legacy', Organization Science, 7 (2), pp. 191207.

Drory, A. (1993). 'Perceived political climate and job attitudes', Organization Studies, 14 (1), pp. 5971.

Drory, A. and T. Romm (1988). 'Politics in organization and its perception within the organization', Organization Studies, 9 (2), pp. 165-179.

Drory, A. and T. Romm (1990). 'The definition of organizational politics: a review', Human Relations, 43 (11), pp. 11331154.

Egan, G. (1994). Working the Shadow Side: A Guide to Positive Behind-the-Scenes Management. San Francisco, CA: JosseyBass.

Eisenhardt, K. M. and L. J. Bourgeois (1988). 'Politics of strategic decision making in high-velocity environments: towards a mid-range theory', Academy of Management Journal, 31(4), pp. 737-770.

Ferris, G. R. and K. M. Kacmar (1992). 'Perceptions of organizational politics', Journal of Management, 18 (1), pp. 93116.

Ferris, G. R. and T. R. King (1991). 'Politics in human resources decisions: a walk on the dark side', Organizational Dynamics, 20 (2), pp. 59-71.

Ferris, G. R., M. R. Buckley and G. M. Allen (1992). 'Promotion systems in organizations', Human Resource Planning, 15 (3), pp. 4768.

Ferris, G. R., D. D. Frink, M. C. Galang, J. Zhou, M. Kacmar and J. L. Howard (1996). 'Perceptions of organizational politics: prediction, stress-related implications, and outcomes', Human Relations, 49 (2), pp. 233266.

Ferris, G. R., P. L. Perrewé, W. P. Anthony and D. C. Gilmore (2000). 'Political skill at work', Organizational Dynamics, 28 (4), pp. 25-37.

Ferris, G. R., G. Adams, R. W. Kolodinsky, W. A. Hochwarter and A. P. Ammeter (2002a). 'Perceptions of organizational politics: theory and research directions', Research in Multilevel Issues, Vol. 1: The Many Faces of Multi-level Issues, pp. 179-254. Amsterdam: Elsevier Science.

Ferris, G. R., W. A. Hochwarter, C. Douglas, F. R. Blass, R. W. Kolodinsky and D. C. Treadway (2002b). 'Social influence processes in organizations and human resource systems', Research in Personnel and Human Resources Management, 21, pp. 65127.

Frost, P. J. and C. P. Egri (1991). 'The political process of innovation'. In L. L. Cummings and B. M. Staw (eds), Research in Organizational Behaviour, pp. 229295. Greenwich, CT: JAI Press.

Gandz, J. and V. V. Murray (1980). 'The experience of workplace politics', Academy of Management Journal, 23, pp. 237251.

Graham, J. H. (1996). 'Machiavellian project managers: do they perform better?', International Journal of Project Management, 14 (2), pp. 6774. 
Hardy, C. (1996). 'Understanding power: bringing about strategic change', British Journal of Management, 7 (special conference issue), pp. 316.

Harrell-Cook, G., G. R. Ferris and J. H. Dulebohn (1999). 'Political behaviors as moderators of the perceptions of organizational politicswork outcomes relationships', Journal of Organizational Behaviour, 20 (7), pp. 10931105.

Harrison, E. F. (1987). The Management Decision-Making Process. Boston, MA: Houghton Mifflin.

Hickson, D. J., C. R. Hinings, C. A. Lee, R. E. Schneck and J. M. Pennings (1971). 'A strategic contingencies theory of intra-organizational power', Administrative Science Quarterly, 16 (2), pp. 216219.

Jackall, R. (1988). Moral Mazes: The World of Corporate Managers. New York: Oxford University Press.

Kacmar, K. M. and D. S. Carlson (1997). 'Further validation of the perceptions of politics scale (POPS): a multiple sample investigation', Journal of Management, 23 (5), pp. 627658.

Kacmar, K. M. and G. R. Ferris (1991). 'Perceptions of organizational politics scale (POPS): development and construct validation', Educational and Psychological Measurement, 51(1), pp. 193205.

Kanter, R. M. (1979). 'Power failure in management circuits', Harvard Business Review, 57(4), pp. 6575.

Keen, P. G. W. (1981). 'Information systems and organizational change', Communications of the ACM, 24 (1), pp. 24-33.

Kipnis, D., S. M. Schmidt, C. Swaffin-Smith and I. Wilkinson (1984). 'Patterns of managerial influence: shotgun managers, tacticians and bystanders', Organizational Dynamics, 12 (3), pp. 58-67.

Klein, J. I. (1988). 'The myth of the corporate political jungle: politicization as a political strategy', Journal of Management Studies, 25 (1), pp. 112.

Kumar, K. and M. Thibodeaux (1990). 'Organizational politics and planned organizational change', Group and Organizational Studies, 15 (4), pp. 357365.

Lincoln, Y. S. and E. Guba (1985). Naturalistic Inquiry. Beverly Hills, CA: Sage.

Machiavelli, N. (1961). The Prince (G. Bull, trans.) London: Penguin.

Madison, D. L., R. W. Allen, L. W. Porter, P. A. Renwick and B. T. Mayes (1980). 'Organizational politics: an exploration of managers' perceptions', Human Relations, 33 (2), pp. 79100.

Mainiero, L. A. (1994). 'On breaking the glass ceiling: the political seasoning of powerful women executives’, Organizational Dynamics, 22 (4), pp. 5-20.

Mangham, I. (1979). The Politics of Organizational Change. Westport, CT: Greenwood Press.

Mann, S. (1995). 'Politics and power in organizations; why women lose out', Leadership and Organization Development Journal, 16 (2), pp. 915.

McClelland, D. C. and D. H. Burnham (1995). 'Power is the great motivator', Harvard Business Review, 73

(1), pp. 126139.

Mintzberg, H. (1983). Power in and around Organizations.

Upper Saddle River, NJ: Prentice Hall.

Mintzberg, H. (1985). 'The organization as political arena', Journal of Management Studies, 22, pp. 133154.

Mohr, L. B. (1982). Explaining Organizational Behaviour: The Limits and Possibilities of Theory and Research. San Francisco, CA: Jossey-Bass.

O'Connor, E. S. (1995). 'Paradoxes of participation: textual analysis and organizational change', Organization Studies, 16 (5), pp. 769-803.

Peled, A. (1999). 'Politicking for success: the missing skill', Leadership and Organizational Change, 21 (1), pp. 20-29.

Perrewé, P. L., G. R. Ferris, D. D. Frink and W. P. Anthony (2000). 'Political skill: an antidote for workplace stressors', Academy of Management Executive, 14 (3), pp. 115123.

Pettigrew, A. M. (1973). The Politics of Organizational Decision-making. London: Tavistock.

Pettigrew, A. M. and T. McNulty (1995). 'Power and influence in and around the boardroom', Human 
Relations, 48 (8), pp. 845-873.

Pfeffer, J. (1992). Managing With Power: Politics and Influence in

Organization. Boston, MA: Harvard Business School Press. Provis, C. (2004). Ethics and Organisational Politics. Cheltenham: Edward Elgar.

Schrijvers, J. P. M. (2004). The Way of the Rat: A Survival Guide to Office Politics. London: Cyan Books.

Stake, R. E. (1994). 'Case studies'. In N. K. Denzin and Y. S. Lincoln (eds), Handbook of Qualitative Research, pp. 236- 247. Thousand Oaks, CA: Sage.

Stoker, L. (2003). 'Is it possible to do quantitative survey research in an interpretive way?', Qualitative Methods, 1 (2), pp. 13-16.

Stone, B. (1997). Confronting Company Politics. Basingstoke: Macmillan Business.

Valle, M and P. L. Perrewé (2000). 'Do politics perceptions relate to political behaviours?: tests of an implicit assumption and expanded model', Human Relations, 53 (3), pp. 359386.

Vigoda, E. (2003). Developments in Organizational Politics: How Political Dynamics Affect Employee Performance in Modern Work Sites. Cheltenham: Edward Elgar.

Vigoda-Gadot, E. and D. Kapun (2005). 'Perceptions of politics and perceived performance in public and private organizations: a test of one model across two sectors', Policy and Politics, 33 (2), pp. 251-276.

Voyer, J. J. (1994). 'Coercive organizational politics and organizational outcomes: an interpretive study', Organization Science, 5 (1), pp. 7285.

Zaleznik, A. (1997). 'Real work', Harvard Business Review, 75 (6), pp. 5363.

David Buchanan is Professor of Organizational Behaviour at Cranfield University School of Management. He holds degrees in business administration and organizational behaviour from HeriotWatt and Edinburgh Universities respectively. He is the author of numerous books and papers on aspects of organizational behaviour. Current research interests include change agency and change management, factors influencing the sustainability and spread of organizational changes, organization politics, and governance systems in healthcare. 